\title{
S sciendo \\ FIRE BEHAVIORS OF THE GEOMATERIAL-BASED COMPOSITE PLASTER COATED BUILDING THERMAL ISOLATION PLATES
}

doi:10.2478/mape-2018-0094

Date of submission of the article to the Editor: 04/2018

Date of acceptance of the article by the Editor: 07/2018

MAPE 2018, volume 1, issue 1, pp. 745-750

\author{
Tamer Rızaoğlu \\ M. Ziya Karataş \\ Kahramanmaraş Sütçü İmam University, Turkey
}

\begin{abstract}
Thermal insulation in buildings has been a problem for mankind throughout history. New materials have always been used in this context, and every new material has negative aspects such as environmental, economic and engineering. Although the building exterior insulation materials produced in recent years have made significant progress in terms of thermal comfort, but those with superior properties in resistance to fire are very limited. In this study, considering the environmental sensitivity, the plasters produced from the sands of arenitized granite, micaschist, pumice and expanded perlite rocks and their combinations were applied on expanded polystyrene (EPS), extruded polystyrene (XPS) foams and mineral wool for investigating the fire behaviors of each material. As a result of fire tests, it was observed that the most positive values were gained from micaschist based external isolation board, whereas the board obtained from arenitized granite gave the most negative values. With the combination of natural and environmentally friendly materials such as micaschist, perlite and pumice, on a fire resistant insulation material such as mineral wool, a highly fire resistant, environmentally sensitive and economical insulation material can be produced.
\end{abstract}

Keywords: composite, fire, prevention, building

\section{INTRODUCTION}

There are many scientific studies on the formation, spreading and prevention of fire in the buildings (Yoshioka et al. 2014; Arpacioğlu, 2004; Oleszkiewicz, 1990; Smolka et al., 2013). Today, the enhancement in the diversity of the materials used in the building exterior walls has increased the importance of the fire safety concept. The formation and spread of the fire on the facades of the building is related to the facade geometry as much as the materials used on the façades (Oleszkiewicz, 1990).

During the fire, there are three different types of ignition for exterior coating surface. The first one is that the flame formed during the fire inside the building rises by lining the outer surface of the building and therefore the external facade elements come to the ignition temperature, the second is the heat or particles coming from the fire next to the building and the third and last ignition source is the heat radiation (Arpacioglu, 2004). Among them, we know that the biggest loss is in the ignition pattern of lining the outer surface in which the amount of heat level by the flame of the area and the fire damage are reached the maximum. The most effective measure against all these types of ignition is the use of nonflammable materials, but when it is thought that it is very difficult to use completely nonflammable materials, serious precautions will be taken if fire resistant materials are used in this area. Exterior Insulation Finishing System (EIFS), which is known as external heat insulation system, uses flammable materials, and studies have been carried out to improve the fire resistance these materials (Jelle et al., 2010; Wade and Clampet, 2000; Ibrahim et al., 2014; White et al., 2003; Barbero et al., 2014). In the upward spreading of facade fires, the flames on the facades can expand beyond the reach of the fire services, spread over the upper floors, making the intervention ineffective or impossible. In this context, often this 
measure is taken with use of non-combustible materials for exterior coatings (Wade and Clampet, 2000).

In this study, the high fire resistance retardancy characteristics of muscovites in micaschists (Hanu, 2010) and the low thermal conductivity coefficient values of natural rocks such as expanded perlite and pumice (Çelik, 2016) evaluated. Considering the environmental sensitivity of natural materials, fire behaviors of insulation panels produced with the application of the plasters made up of some geomaterials and their combinations and commonly used exterior insulation materials such as Expanded Polystyrene foam (EPS), Extruded Polystyrene foam (XPS) and Mineral wool were investigated. Similar experiments were done on some different types of façade cladding samples by some researchers (Yoshioka et al., 2014; Christensen, 1995; Uygunoğlu, 2015).

\section{MATERIALS AND METHODS}

The basic materials used in this study are the mortars obtained from the combination of cement and sand derived from various lithologies (micaschist, arenitized granite, pumice and expanded perlite) to form the building exterior isolation board. Micaschist samples were obtained from the foliated rocks of the Paleozoic Malatya metamorphics in the Berit region to the north of Kahramanmaras city, Turkey. The pumice samples were derived from Kaymaklı Acidic Pumice field in Nevşehir region in central Anatolia. The acidic pumice show vesicular and glassy texture and have approximately $75-80 \%$ of cavities. The expanded perlite samples were obtained from a company in Bergama county of İmir city in the western part of Turkey. The arenitized granite is from the arenitized section of Late Cretaceous Esence Granitoid located in the south of Afşin county in Kahramanmaraş city, Turkey. CEM-1 42,5 R portland cement was used with the sands from the lithological units mentioned above to produce the mortar. For the production of thermal isolation plates, three different kinds of building cladding materials (Expanded Polystyrene foam (EPS), Extruded Polystyrene foam (XPS) and Mineral wool) were used together with the mortar with the same method and combinations used by Karataş and Rizaoğlu (2017) (Table 1).

Table 1

The composition of the samples.

\begin{tabular}{|c|c|}
\hline SAMPLE & COMBINATIONS \\
\hline MZK-1 & Pumice+Cement+Water \\
\hline MZK-2 & Granite+Cement+Water \\
\hline MZK-3 & Perlite+ Cement+Water \\
\hline MZK-4 & Micaschist+ Cement+Water \\
\hline MZK-5 & Micaschist+ Granite+ Cement+Water \\
\hline MZK-6 & Micaschist+ Pumice+ Cement+Water \\
\hline MZK-7 & Pumice+ Granite+ Cement+Water \\
\hline MZK-8 & Pumice+ Perlite+ Cement+Water \\
\hline MZK-9 & Perlite+ Granite+ Cement+Water \\
\hline MZK-10 & Perlite+ Micaschist+ Cement+Water \\
\hline
\end{tabular}

To increase the adhesion strength of the mortar on the plates, glass fiber plaster mesh (160 $\left.\mathrm{g} / \mathrm{m}^{2} 4 \times 4\right)$ was used. Before preparing the test samples, $1350 \mathrm{~g}$ aggregates $(1 / 3$ fine and $2 / 3$ of coarse aggregate), $450 \mathrm{~g}$ cement, and $225 \mathrm{~g}$ water were mixed. Coarse aggregate was between 1-2 $\mathrm{mm}$ and fine aggregate was $0-1 \mathrm{~mm}$ in size.

In the thermal isolation board samples preparation stage, after making a thin first layer (0.5-1 $\mathrm{mm}$ ) of plaster, glass fiber plaster mesh was applied to make the plaster fixed. Next, the 
second layer of plaster was applied with an optimum thickness. At the final stage, the cladding plate production was made with topcoat plastered with natural material combinations. The samples were dried before the tests.

Plaster mortar coated samples were tested using a single fire source with a linear fire propagation after 28 days of waiting (Figure 1a). During the experiment, the samples were exposed to $20 \mathrm{~mm}$ high flame (Figure 1b). In the experiment, the gas pressure and gas flow in the appropriate range were determined and performed in the same manner in all samples. The flame from the source was applied to the outer surfaces covered by the plaster at a $45^{\circ}$ angle for 4 minutes (Figure 1b,c).

When the test was carried out, the specimens of $40 \times 100 \times 250 \mathrm{~mm}$ prepared to conduct the flame test from the flame source were determined to be $40 \mathrm{~mm}$ above the bottom of the coating surfaces and then ready to be tested (Figure 1c). Finally, the temperature values at the end of the envelope were measured with an infrared thermometer for 4 minutes during which they were exposed to the flame from the outer surface and the surface temperature values were noted (Table 2) (Figure 1d).

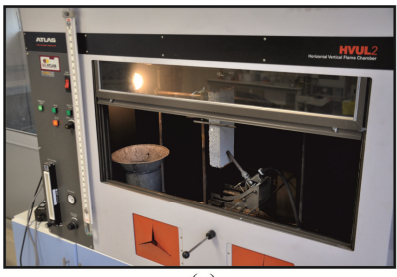

(a)

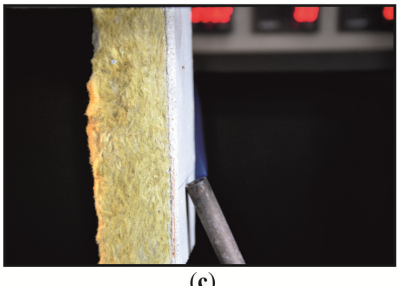

(c)

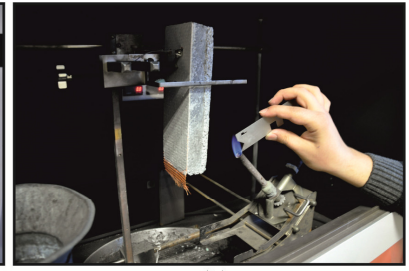

(b)

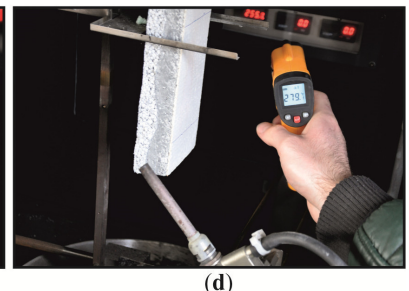

Fig 1. The stages of fire test (a) fire test instrument, (b) flame length measurement, (c) testing, (d) temperature measurement by infra-red thermometer.

The specimens exposed to the flame on the fire test apparatus were taken and cooled at room temperature and then cut longitudinally with a saw to investigate different behavior deformations. After the plaster-coated specimens were cut, the height and depth of the burning occurred as a result of destruction in the rear parts were measured (Table 2).

Table 2

Fire test results of isolation panels

\begin{tabular}{|c|c|c|c|c|c|c|c|}
\hline \multirow{2}{*}{ Sample } & \multicolumn{2}{|c|}{ External surface temperature $\left({ }^{\circ} \mathbf{C}\right)$} & \multicolumn{2}{c|}{ Burning height $(\mathbf{m m})$} & \multicolumn{2}{c|}{ Burning depth $(\mathbf{m m})$} \\
\cline { 2 - 8 } & Mineral wool & XPS & EPS & XPS & EPS & XPS & EPS \\
\hline MZK-1 & 318.5 & 285.6 & 235.2 & 120.8 & 130.1 & 37.8 & 39.8 \\
\hline MZK-2 & 245.9 & 230.7 & 219.5 & 140.1 & 160.5 & 39.1 & 40.0 \\
\hline MZK-3 & 388.7 & 311.4 & 283.3 & 100.9 & 110.9 & 32.2 & 39.1 \\
\hline MZK-4 & 398.8 & 350.3 & 336.6 & 78.6 & 87.3 & 26.8 & 37.9 \\
\hline MZK-5 & 357.4 & 306.6 & 262.3 & 110.8 & 130.2 & 35.3 & 40.0 \\
\hline MZK-6 & 278.9 & 261.8 & 231.9 & 110.2 & 120.1 & 31.2 & 39.6 \\
\hline MZK-7 & 256.5 & 232.6 & 185.1 & 120.9 & 150.2 & 37.3 & 40.0 \\
\hline MZK-8 & 170.3 & 135.4 & 106.3 & 110.4 & 120.8 & 34.4 & 39.7 \\
\hline MZK-9 & 354.8 & 238.5 & 159.3 & 120.8 & 140.1 & 36.7 & 40.0 \\
\hline MZK-10 & 377.4 & 238.5 & 218.1 & 100.6 & 110.3 & 29.8 & 38.9 \\
\hline
\end{tabular}




\section{RESULTS AND DISCUSSION}

One of the most important results of this work is the temperature distribution on the surface of the external cladding composites exposed to the flame. The highest values were observed in the micaschist based boards due to superb combustion delaying capacity of muscovite (Hanu, 2010) on the other hand the lowest values were read in compositions including arenitized granite. (Table 2) (Figure 2a). The mineralogical composition of the arenitized granite used in the study is represented by quartz, K-feldspar, plagioclase, mica and hornblende (Rizaoğlu et al., 2005). The quartz in the arenitized granite causes destruction in a wide surface area due to its low melting point and thus the rapid transmission of heat inside it. In general terms, the temperatures on the surface of the specimens subjected to the experiment upwards decrease as they move away from the flame. In other words, if the extreme point is taken from the surface, values are taken before they are almost exposed to flame.

The values of the burning height and depth of the samples exposed to the flame were measured with the aid of a caliper behind the plaster and given in Table 2 and Figure 2b,c. Specimens burned rapidly up to 4 minute and after 4 minutes, the burning speed determined as less than 0-4 minutes between 4 and 9 minutes. After 9 minute, almost no decrease was observed and then the optimum threshold value was determined as 4 minutes. At the end of the 4 minute standard flame exposure period, there was more deformation in EPS insulation materials than in the XPS in terms of combustion heights. The highest fire height value reached by EPS was $160,5 \mathrm{~mm}$ in arenitized granite (MZK-2) and the lowest value was measured in micaschist (MZK-4) as $87.3 \mathrm{~mm}$. In XPS, the maximum and minimum height values were measured in the same samples between $140.1 \mathrm{~mm}$ and $78.4 \mathrm{~mm}$ respectively (Table2) (Figure 2b). On the fire depth, the positive effects of the micaschist is clearly seen (Table 2). Due to its resistance to heat transmission, the lowest values were measured from micaschist isolation boards (26.8 $\mathrm{mm}$ in XPS and $37.9 \mathrm{~mm}$ in EPS) whereas the highest values were reached on the boards from arenitized granite or the compositions including it ranging from $39.1 \mathrm{~mm}$ to $40 \mathrm{~mm}$ due to heat transfer characteristics of the quartz which is abundant mineral of arenitized granite (Table 2) (Figure 2c).

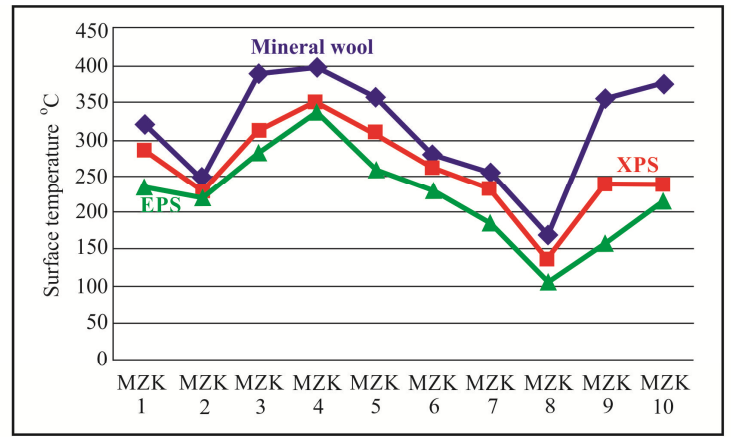

(a)

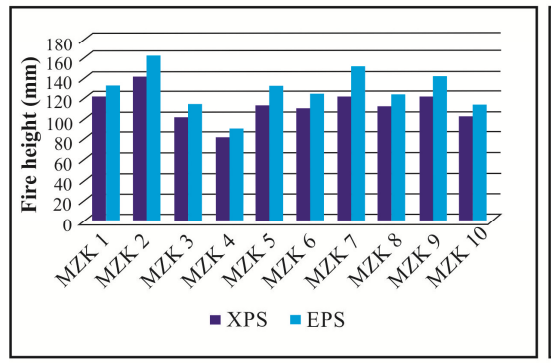

(b)

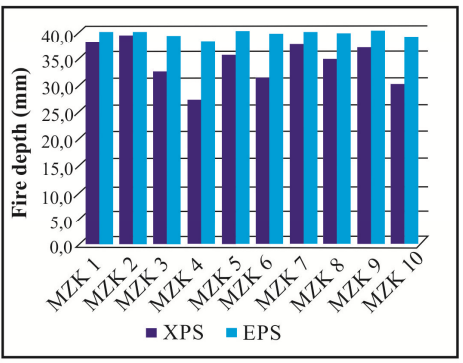

(c)

Fig. 2. (a) surface temperature, (b) fire height, (c) fire depth graphics of the samples from different compositions of thermal isolation boards 
The general deformations in the rear parts of the thermal insulation plates exposed to the flame during the test are given in Figure $3 a$

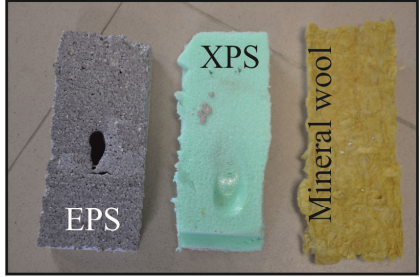

(a)

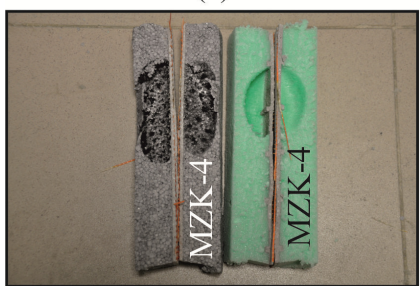

(c)

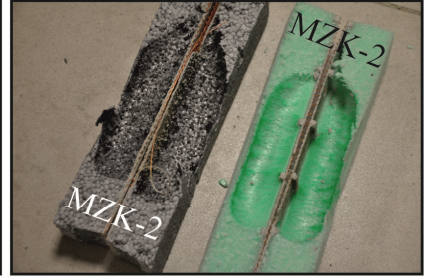

(b)

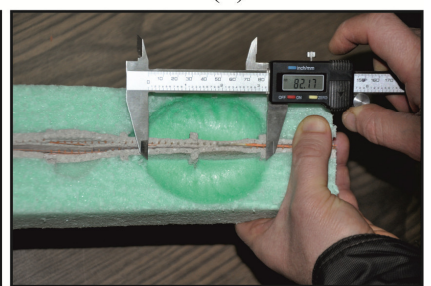

(d)

Figure 3. Deformation forms (a) in general (b) in arenitized granite based boards, (c) in arenitized granite and micaschist boards, (d) fire height measurement

Except for micaschists and combinations in all samples of EPS material-based insulation boards, a visible deformation was observed in the entire back of the boards. In XPS specimens, a deformation reaching to the rear part is not observed in general and the deformation reaching to $4 \mathrm{~mm}$ thickness as a general condition is observed only in arenitized granite coated board (Figure 3b).

Since the mineral wool is incombustible material, no deformation was observed in all combinations (Figure 3a). Samples were cut longitudinally from the center by a saw, and the greatest damage was observed in the arenitized granite board (MZK-2) while the least deformation was observed in the micaschist coated board (MZK 4) (Figure 3c). The measurements were taken with the help of calipers to observe the damage (Figure 3d). As a result, no burning or deformation has been observed in the plaster files.

During the fire, there is an empty area on the back surfaces of the burning parts of the EPS and XPS specimens, since it is expected that there will be no base material to hold on the rear parts of the coating surfaces exposed to the flame for a long time. In this case, it is expected that the outer surface of the welded surfaces will fall down due to the disappearance of the attachment surfaces. This will present another danger during the fire. This presents the problem of life safety for the people who are saved during the fire and contains serious threats. The fact that the exterior wall mesh is incombustible and its effect on strength is inevitable.

\section{CONCLUSIONS}

Within the scope of the study, research conducted on the surface temperatures and deformation patterns of the thermal insulation boards produced by applying the plasters of different rocks and their combinations on the most preferred materials in the building exterior insulation (EPS, XPS and Rock Wool) with $20 \mathrm{~mm}$ flame height in 4 minutes time and the following results were obtained.

The highest surface temperature is measured in boards with micaschist (MZK-4) and the lowest in arenitized granite (MZK-2), which is in direct proportion to the high temperature holding capacities of mica minerals. In the case of arenitized granite based boards, quartz minerals have low temperature keeping capacity values due to their good thermal conductivity and they show high deformation in their lower parts.

Burning height and depth values also showed parallel results with the same burning temperature,displaying the highest fire resistance in micaschists and low burning height and 
depth values. The maximum burning height and depth values were obtained in composite plaster made from arenitized granite. It is observed that these materials have the same effect on other combinations they mix.

No deformation or burning of the plaster mesh was observed during the experiment. During the exposure of the materials to the flame, due to the spaces that will form behind the plaster, it is not possible to carry the load on it and it creates the risk of loss of life during the fire. As a result of the experimental study, it can be considered that insulation materials should be used in higher thicknesses in which the thicknesses specified in the regulation are not actually sufficient in this study. Although the boards with micaschist obtained in this study did not have the quality to stop the fire, positive results were obtained in order to increase the evacuation time during the fire. In this context, it is expected that the use of mineral wool together with the mixtures including micaschist on composite plaster boards will provide a considerable contribution to the increase of the fire resistance. The natural rock materials will also give positive effects of environment.

\section{ACKNOWLEDGEMENTS}

The tested samples'combinations are from the Msc thesis of Muhammed Ziya Karataş. Kahramanmaraş Sütçü Imam University Research Foundation (Project Number: 2016/51YLS) is greatly acknowledged for finacial support. We would like to thank Prof. Dr. Hakkı ALMA for allowing us to use the fire test facilities in the laboratory of KSU Faculty of Forestry. Canberk COŞKUN is also thanked for his kind help during the fire test.

\section{REFERENCES}

Arpacioğlu, Ü. (2004). Cephe Yangınları ve Cephe Kaplamalarının Yangın Güvenliği Açısından Değerlendirilmesi, Çatıder, Çatı Cephe Fuarı, CNR, İstanbul, Türkiye.

Barbero, S., Dutto, M., Ferrua, C. and Pereno, A. (2014). Analysis on existent thermal insulating plasters towards innovative applications: Evaluation methodology for a real cost-performance comparison. Energy and Buildings, 77, 40-47.

Celik, S., Family, R. and Menguc, M.P. (2016). Analysis of perlite and pumice based building insulation materials. Journal of Building Engineering, 6,105-111.

Christensen, G.L. (1995). Full-scale Fire Test of Various Exterior Wall Systems. ASTM Special Technical Publication, 1187,27.

Hanu, L.G., Simon, G.P. and Cheng, Y.B. (2006). Thermal stability and flammability of silicone polymer composites. Polymer Degradation and Stability, 91(6), 1373-1379.

Ibrahim, M., Biwole, P.H., Achard, P. and Wurtz, E. (2014). Aerogel-based coating for energy-efficient building envelopes. 9th international energy forum on advanced building skins, Bressanone, Italy, 753-774.

Jelle, B.P., Gustavsen, A. and Baetens, R. (2010). The path to the high performance thermal building insulation materials and solutions of tomorrow. Journal of Building Physics, 34(2), 99-123.

Karataş, M.Z. and Rizaoğlu, T. (2017). Technical Characteristics of Building Isolation Plates Produced From Natural Materials Such As: Perlite, Pumice Micaschist and Arenitized Granite. Revista Romana De Materiale-Romanian Journal of Materials, 47(2), 244-251

Oleszkiewicz, I., (1990). Fire exposure to exterior walls and flame spread on combustible cladding. Fire Technology, 26(4), 357-375.

Rizaoğlu, T., Parlak, O. and İşler, F., (2005). Esence granitoyidinin (Göksun-Kahramanmaraş) jeokimyası, GD Türkiye. Yerbilimleri Dergisi, 26(1), 1-13.

Smolka, M., Messerschmidt, B., Scott, J. and Le Madec, B. (2013). Semi-natural test methods to evaluate fire safety of Wall Claddings, Rockwool International A/S, Hedehusene, Denmark, MATEC Web of Conferences, 9, 02012.

Uygunoğlu, T., Güneş, İ., Çaliş, M. and Özgüven, S. (2015). EPS ve XPS Malzemeleriyle Yapılan Mantolamaların Yangın Sırasındaki Davranışlarının Araştııııması, Politeknik Dergisi, 18(1), 2128.

Wade, C.A. and Clampett, J.C. (2000). Fire Performance of Exterior Claddings, Fire Code Research Reform Program, Project Report, FCRC PR: 00-03

White, N., Delichatsios, M., Ahrens, M. and Kimball, A. (2003). Fire hazards of exterior wall assemblies containing combustible components. MATEC Web of Conferences, 9, 02005, 1-12.

Yoshioka, H., Nishio, Y., Tamura, M., Yoshida, M., Noguchi, T., Ohmiya, Y., Kanematsu, M., Ando, T., Koura, K., Tomatsu, T. and Ozaki, Y., (2014). Façade tests on fire propagation along combustible exterior wall systems. Fire Science and Technology, 33(1), 1-15. 